\title{
Phytoprotection
}

\section{The influence of chitin-urea amendments applied to an organic soil on a Meloidogyne hapla population and on the growth of greenhouse tomato}

\section{G. Bélair et N. Tremblay}

Volume 76, numéro 2, 1995

URI : https://id.erudit.org/iderudit/706087ar

DOI : https://doi.org/10.7202/706087ar

Aller au sommaire du numéro

Éditeur(s)

Société de protection des plantes du Québec (SPPQ)l

ISSN

0031-9511 (imprimé)

1710-1603 (numérique)

Découvrir la revue

Citer cet article

Bélair, G. \& Tremblay, N. (1995). The influence of chitin-urea amendments applied to an organic soil on a Meloidogyne hapla population and on the growth of greenhouse tomato. Phytoprotection, 76(2), 75-80.

https://doi.org/10.7202/706087ar
Résumé de l'article

Cette expérience a été réalisée en serre dans le but d'évaluer l'efficacité d'un amendement à base de chitine-urée appliqué à un sol organique dans le but de réprimer une population du nématode des nodosités (Meloidogyne hapla) provenant du Québec et de déterminer le pouvoir pathogène de ce nématode sur une culture de tomate (Lycopersicon esculentum). Les amendements de chitine-urée, aux doses de 0,2 et $0,4 \%$ (vol:vol), n'ont pas réduit les populations du nématode présentes avant la plantation. Les populations finales d'œufs de $M$. hapla ont été significativement augmentées dans les sols amendés avec la chitine-urée et un effet significatif positif de la dose a été enregistré. Le feuillage de tomate a été significativement réduit en présence de $M$. hapla, et accru par l'amendement de chitine-urée. À la récolte, le poids des fruits n'a pas été affecté par la présence du M. hapla ni par la chitine-urée. Les populations finales d'oeufs de $M$. hapla étaient associées avec des teneurs réduites en $\mathrm{N}$ et $\mathrm{P}$, mais accrues en $\mathrm{Ca}$ dans les tissus foliaires. 


\title{
The influence of chitin-urea amendments applied to an organic soil on a Meloidogyne hapla population and on the growth of greenhouse tomato
}

\author{
Guy Bélair and Nicolas Tremblay ${ }^{1}$
}

Received 1995-03-22; accepted 1995-09-17

This experiment was conducted under greenhouse conditions to evaluate the efficiency of chitin-urea amendments to an organic soil against a Quebec population of the northern root-knot nematode (Meloidogyne hapla) and to assess the pathogenicity of this population on tomato (Lycopersicon esculentum). Chitin-urea amendments at 0.2 and $0.4 \%$ (vol:vol) were ineffective in reducing the preplant nematode populations. The final $M$. hapla egg populations were significantly increased in chitin-urea amended soils, and a significant positive dosage effect was recorded. Shoot growth of tomato plants was significantly reduced by $M$. hapla but was increased by chitin-urea. At harvest, fruit weights were neither affected by $M$. hapla nor by chitin-urea amendments. The final $M$. hapla egg population was linked to lower $N$ and $P$ levels, and to higher $\mathrm{Ca}$ levels in leaf tissues.

Bélair, G. et N. Tremblay. 1995. Effet d'un amendement de sol à base de chitine-urée sur une population de Meloidogyne hapla et sur la croissance de la tomate de serre dans un sol organique. PHYTOPROTECTION 76 : 75-80.

Cette expérience a été réalisée en serre dans le but d'évaluer l'efficacité d'un amendement à base de chitine-urée appliqué à un sol organique dans le but de réprimer une population du nématode des nodosités (Meloidogyne hapla) provenant du Québec et de déterminer le pouvoir pathogène de ce nématode sur une culture de tomate (Lycopersicon esculentum). Les amendements de chitine-urée, aux doses de 0,2 et 0,4\% (vol:vol), n'ont pas réduit les populations du nématode présentes avant la plantation. Les populations finales d'oeufs de $M$. hapla ont été significativement augmentées dans les sols amendés avec la chitine-urée et un effet significatif positif de la dose a été enregistré. Le feuillage de tomate a été significativement réduit en présence de $M$. hapla, et accru par l'amendement de chitine-urée. À la récolte, le poids des fruits n'a pas été affecté par la présence du $M$. hapla ni par la chitine-urée. Les populations finales d'oeufs de $M$. hapla étaient associées avec des teneurs réduites en $\mathrm{N}$ et $\mathrm{P}$, mais accrues en $\mathrm{Ca}$ dans les tissus foliaires.

\section{INTRODUCTION}

The northern root-knot nematode (Meloidogyne hapla Chitwood) parasitizes and reproduces on vegetable crops including tomato (Lycopersicon esculentum L.). Several attempts to relate initial M. hapla populations to growth and yield of tomatoes resulted in variable responses under both greenhouse and field conditions. Fawole and Mai (1979) reported that $M$. hapla did not limit tomato growth after $6 \mathrm{wk}$ under greenhouse conditions. Under field conditions, Barker et al. (1976) reported that yield reductions due to $M$. hapla ranged $10-50 \%$ depending on

1. Agriculture and Agri-Food Canada, 430, Gouin blvd., Saint-Jean-sur-Richelieu, Quebec, Canada J3B 3E6. Contribution No. 335/95.12.01R 
the soil type and the geoclimatological area. Olthof and Potter (1977) reported that a density of $27950 \mathrm{M}$. hapla larvae $\mathrm{kg}^{-1}$ of soil delayed tomato fruit ripening. Low to moderate densities (up to 2000 larvae $\mathrm{kg}^{-1}$ soil) increased total yield of fruit while densities above 2000 larvae $\mathrm{kg}^{-1}$ reduced total yield. Sayre and Toyama (1964) showed that low and medium population densities of M. hapla (220 and 1980 larvae $\mathrm{kg}^{-1}$ soil) increased the number and weight of processing tomatoes. Stephan (1983) found that a Canadian $M$. hapla population was less damaging to tomato cv. Rutgers than were American and English populations. So far, the pathogenicity of $M$. hapla populations from Quebec to greenhouse tomato has not been investigated.

Root diseases are a major obstacle in organically-grown or pesticide-free tomatoes in Quebec (Carrier 1992). Severe infestations of $M$. hapla occur and are believed to adversely affect growth and productivity. Because this type of production cannot rely on synthetic pesticides for pest management, growers need alternative methods. Among organic soil amendments reported to suppress plantparasitic nematodes (Rodriguez-Kabana et al. 1987), chitin has been effective repeatedly against root-knot nematodes (Mankau and Das 1969; Mian et al. 1982). The nematicidal activity of chitin and chitin-urea amendments is attributed to the release of nematicidal levels of ammoniacal nitrogen, combined with the enzymatic activity of chitinolytic microorganisms or with parasitism on plantparasitic nematodes (Mian et al. 1982; Rodriguez-Kabana et al. 1984, 1987).

This experiment was conducted to evaluate the efficiency of chitin-urea soil amendment in an organic soil against $M$. hapla and to assess the pathogenicity of a population of this nematode from Quebec to tomato cv. Caruso under greenhouse conditions.

\section{MATERIALS AND METHODS}

Field soil from an experimental carrot (Daucus carota L.) plot in Sainte-Clotilde, Quebec, (lat. $45^{\circ} 25^{\prime} \mathrm{N}$ long. $73^{\circ} 41^{\prime} \mathrm{W}$ ) infested with $M$. hapla was used as inoculum. The soil was a fibrosol with $\mathrm{pH}$ 4.5-
$5.5,80 \%$ organic matter and a $\mathrm{C}: \mathrm{N}$ ratio of $18: 1$. Half of the bulk soil was pasteurized for the controls without nematode, and stored for $2 \mathrm{mo}$ at room temperature before use. The experiment was a factorial arrangement of three levels of chitinurea amendment (ClandoSan 618, Igene Biotechnology Inc., Columbia, MD) at 0 , 0.2 , and $0.4 \%$ vol:vol, and two nematode densities $(0$ and $1520 \mathrm{M}$. hapla juveniles per $100 \mathrm{~cm}^{3}$ of soil) in a randomized complete block design with five replicates. The nematode population density was estimated by processing ten $100-\mathrm{cm}^{3}$ subsamples by the modified Baermann pan method (Townshend 1963). The $M$. hapla population density was estimated at 1520 juveniles per $100 \mathrm{~cm}^{3}$ of soil [an average of $532 \pm 86$ juveniles per $100 \mathrm{~cm}^{3}$ soil with an extraction efficiency of $35 \%$ (Bélair, unpublished data)].

The chitin-urea granules were mixed in a concrete mixer with field soil and then transferred to $10-\mathrm{L}$ plastic pails $(28 \mathrm{~cm} x$ $18 \mathrm{~cm} \times 27 \mathrm{~cm})$. Soil moisture was adjusted to field capacity ( $3 \mathrm{kPa})$. The pails were placed in a greenhouse at $25 \pm 2^{\circ} \mathrm{C}$ for $28 \mathrm{~d}$ to allow for partial decomposition of chitin. A 1-mo-old tomato cV. Caruso plant grown in pasteurized organic soil was transplanted in each pail. Pretransplant soil nematode derisities were assessed from a $100-\mathrm{cm}^{3}$ subsample recovered from each pail and processed as mentioned above. The greenhouse conditions were as follows : temperature, $24 \pm 2^{\circ} \mathrm{C}$, and relative humidity, $55 \pm 10 \%$. Supplementary lighting at $275 \mu \mathrm{mol} \mathrm{m} \mathrm{m}^{-2} \mathrm{~s}^{-1}$ PAR was provided by high pressure sodium lamps with a 16-h photoperiod. Plants were watered daily and fertilized weekly with an all-purpose NPK (20-20-20) fertilizer (Plant Product ${ }^{\circledR}$ ). Three weeks after transplanting, plants were topped by removing all tissues beyond the $3^{\text {rd }}$ leaf above the last flower cluster in full bloom. Plants were also trimmed twice as follows : $7 \mathrm{wk}$ after transplanting, the first six bottom leaves were removed ( $1^{\text {st }}$ trimming); $1 \mathrm{wk}$ later, the next three lower leaves were removed $\left(2^{\text {nd }}\right.$ trimming $)$. After drying, the foliage trimmings were weighed and processed for chemical analysis. $\mathrm{N}$ and $\mathrm{P}$ analyses were done colorimetrically using the Technicon AutoAnalyser II Industrial Method No. 334-74W/B+ (Elmsford, NY). 
Analyses of $\mathrm{K}, \mathrm{Ca}, \mathrm{Mg}, \mathrm{Fe}, \mathrm{Mn}, \mathrm{Cu}, \mathrm{Zn}$ and $B$ in tissues were done by ICP-AES on a Jarrel-Ash Model ICAP-9000 (Isaac and Johnson 1976).

Starting 10 wk after transplanting, ripe fruits were harvested every 3-4 d and weighed. At the end of the 6 -wk picking period, all remaining fruits were removed and weighed. The experiment ended $114 \mathrm{~d}$ after transplanting. Roots were carefully separated from soil by shaking and rinsing under running water, dried between paper towels to remove excess water, and weighed. Shoot dry wt from the two trimmings, fresh root weight, yield (total number of fruit, and total fruit weight), root galling (0-10 scale where $0=$ no galls, and $10=100 \%$ galled), and number of eggs plant ${ }^{-1}$ were determined.

Data were analyzed by SAS GLM procedure (SAS Institute 1988) and treatment means were separated by linear contrasts. Nematode data were transformed by $\left(\log _{10}[x+1]\right)$ to achieve homogeneity of variance.

\section{RESULTS}

At transplanting, numbers of $M$. hapla second-stage juveniles ranged $486-1828$ larvae per $100 \mathrm{~cm}^{3}$ in soil samples and were not affected by chitin-urea amendments (Table 1). At harvest, root-knot nematode galling on tomato roots was severe on all nematode-infested plants, with no significant difference between chitin-urea treatment and untreated control. Total $M$. hapla egg populations were significantly higher on chitin-urea treated plants than on control plants, and were higher on plants treated with the high rate versus the low rate.
Weights of trimmed leaves were significantly reduced by $M$. hapla infection but were increased by the chitin-urea treatment at the $1^{\text {st }}$ trimming (Table 2). At the $2^{\text {nd }}$ trimming, leaf weights were significantly greater in chitin-urea treatment than in the control, with a significant positive rate effect. Root weights of $M$. hapla infested plants were increased by $186 \%$ on average as compared to the control. Total number and weight of fruits were not affected by chitin-urea treatment or M. hapla infestation.

The final M. hapla egg populations were linked to lower $N$ and $P$, but linked to higher $\mathrm{Ca}$ in leaf tissues (Table 3). Chitinurea increased $\mathrm{N}$ but reduced $\mathrm{P}$ concentrations in leaf tissues. B concentration in leaf tissues was increased by $10 \%$ with M. hapla while $\mathrm{Mn}$ and $\mathrm{Zn}$ concentrations were reduced by $400 \%$ and $36 \%$, respectively. Fe and $\mathrm{Zn}$ concentrations increased with chitin-urea level.

\section{DISCUSSION}

In organic soil, chitin-urea amendments at 0.2 and $0.4 \%$ (vol:vol) rates were ineffective in controlling initial and final M. hapla population densities on tomato plants. The reproduction rate of the nematode was actually increased in amended soils. Roots may have benefited from an improvement of physicochemical properties following the amendment (Shelter and Effmert 1987). Top growth of tomato plants was stimulated in chitin-urea treatments, probably as a result of the nitrogen content of the amendment.

Table 1. Influence of a chitin-urea soil amendment on population density and root galling of $M$. hapla on greenhouse tomato cv. Caruso

\begin{tabular}{lccc}
\hline $\begin{array}{l}\text { Chitin-urea rate } \\
\text { (\% vol:vol) }\end{array}$ & $\begin{array}{c}\text { Initial population } \\
\text { (juveniles } 100 \mathrm{~cm}^{-3} \text { soil) }\end{array}$ & $\begin{array}{c}\text { Root galling } \\
(0-10)^{\mathrm{b}}\end{array}$ & $\begin{array}{c}\text { Final population } \\
\left(\times 10^{6} \text { eggs plant }^{-1}\right)\end{array}$ \\
\hline 0 & 1274 & 8.0 & 5.38 \\
0.2 & 994 & 7.6 & 6.79 \\
0.4 & 1183 & 8.6 & 13.40 \\
Contrasts & & & $*$ \\
Chitin vs. without chitin & $\mathrm{NS}$ & $\mathrm{NS}$ & NS \\
Single vs. double rate & $\mathrm{NS}$ & $* *$ \\
\hline
\end{tabular}

${ }^{*},{ }^{*}=$ significant at $P \leq 0.05$ and $P \leq 0.01$, respectively.

a Population at transplanting time.

${ }^{b}$ Root galling index $=1-10(0=$ no galls, $10=100 \%$ galled $)$. 
Table 2. Growth and yield of tomato cv. Caruso as affected by chitin-urea soil amendmerit and M. hapla infestations

\begin{tabular}{|c|c|c|c|c|c|}
\hline \multirow{2}{*}{$\begin{array}{l}\text { Chitin-urea rate } \\
\text { (\% vol:vol) }\end{array}$} & \multicolumn{2}{|c|}{$\begin{array}{l}\text { Leaf dry wta } \\
\quad\left(\text { g plant }^{-1}\right)\end{array}$} & \multirow{2}{*}{$\begin{array}{l}\text { Root fresh wt } \\
\quad\left(\mathrm{g} \text { plant }^{-1}\right)\end{array}$} & \multirow{2}{*}{$\begin{array}{l}\text { Total } \\
\text { fruit wt } \\
(\mathrm{kg})\end{array}$} & \multirow{2}{*}{$\begin{array}{l}\text { Total } \\
\text { no. of } \\
\text { fruits }\end{array}$} \\
\hline & $1^{\text {st }}$ & $2^{\text {nd }}$ & & & \\
\hline \multicolumn{6}{|l|}{ Without M. hapla } \\
\hline 0 & 4.2 & 69.5 & 78.4 & 1.70 & 13.2 \\
\hline 0.2 & 7.2 & 88.6 & 98.7 & 1.70 & 12.4 \\
\hline 0.4 & 8.3 & 89.4 & 93.6 & 1.85 & 13.4 \\
\hline \multicolumn{6}{|l|}{ With M. hapla } \\
\hline 0 & 3.2 & 75.8 & 151.3 & 1.80 & 12.4 \\
\hline 0.2 & 4.2 & 86.8 & 133.8 & 1.74 & 14.6 \\
\hline 0.4 & 4.4 & 104.3 & 216.1 & 1.69 & 15.2 \\
\hline \multicolumn{6}{|l|}{ Contrasts } \\
\hline M. hapla vs. without $M$. hapla & ** & NS & $* *$ & NS & NS \\
\hline Chitin-urea vs. without chitin-urea & $*$ & ** & NS & NS & NS \\
\hline Single vs. double rate & NS & * & NS & NS & NS \\
\hline Interaction & NS & NS & NS & NS & NS \\
\hline
\end{tabular}

* ** ${ }^{*}$ significant at $P \leq 0.05$ and $P \leq 0.01$, respectively.

a Total dry wt of leaf per plant at the first and second trimming.

Table 3. The effect of chitin-urea soil amendment and $M$. hapla on mineral content of tomato leaves recovered from the first trimming

\begin{tabular}{|c|c|c|c|c|c|c|c|c|c|}
\hline \multirow{2}{*}{$\begin{array}{l}\text { Chitin-urea rate } \\
\text { (\% vol:vol) }\end{array}$} & $\mathrm{N}$ & $P$ & $\mathrm{~K}$ & $\mathrm{Mg}$ & $\mathrm{Ca}$ & B & $\mathrm{Fe}$ & $\mathrm{Mn}$ & $\mathrm{Zn}$ \\
\hline & \multicolumn{5}{|c|}{ (g $100 \mathrm{~g}^{-1}$ d.m.) } & \multicolumn{4}{|c|}{ ( $\mu \mathrm{g} \mathrm{g}^{-1}$ d.m.) } \\
\hline \multicolumn{10}{|l|}{ Without M. hapla } \\
\hline 0 & 3.94 & 1.29 & 2.89 & 0.53 & 3.49 & 97.0 & 88.6 & 260.4 & 15.2 \\
\hline 0.2 & 4.29 & 1.27 & 2.54 & 0.60 & 3.64 & 87.0 & 99.2 & 225.6 & 18.6 \\
\hline 0.4 & 4.56 & 1.23 & 3.24 & 0.57 & 3.37 & 88.2 & 111.6 & 252.8 & 24.6 \\
\hline \multicolumn{10}{|l|}{ With M. hapla } \\
\hline 0 & 3.80 & 1.17 & 2.98 & 0.52 & 3.77 & 107.4 & 91.2 & 64.6 & 10.6 \\
\hline 0.2 & 4.01 & 1.05 & 2.60 & 0.52 & 4.20 & 109.0 & 92.2 & 59.2 & 12.0 \\
\hline 0.4 & 4.27 & 0.95 & 2.37 & 0.57 & 4.35 & 105.8 & 124.0 & 50.0 & 17.2 \\
\hline \multicolumn{10}{|l|}{ Contrasts } \\
\hline M. hapla vs. without $M$. hapla & * & $* *$ & NS & NS & ** & ** & NS & $* *$ & ** \\
\hline Chitin-urea vs. without chitin-urea & $* *$ & $*$ & NS & NS & NS & NS & ** & NS & ** \\
\hline Single vs. double rate & NS & NS & NS & NS & NS & NS & ** & NS & $* *$ \\
\hline Interaction & NS & NS & NS & NS & NS & NS & $*$ & NS & NS \\
\hline
\end{tabular}

${ }^{*},{ }^{*}=$ significantly different at $P \leq 0.05$ and $P \leq 0.01$, respectively.

Chitin decomposition releases ammonia, which acts as a nematicide with a plasmolyzing effect on the infective second-stage juveniles (Spiegel et al. 1987). Chemical soil properties such as $\mathrm{pH}$ influence the effectiveness of chitinous amendments (Spiegel et al. 1986). In acidic soil, more $\mathrm{NH}_{4}^{+}$ion and less ammonia would be present, so again the plasmolyzing effect of ammonia would be lessened. In organic soils, the carbon content is often relatively high; a $\mathrm{C}: \mathrm{N}$ ratio of 20 or more could inactivate ammonia as a nematoxic compound by stimulating a rapid shift to nitrate (RodriguezKabana et al. 1987). Results from this experiment support these hypotheses. Plant yields were not affected by the nematode, nor by the amendments. It is possible that the chitin amendmerit and soluble fertilization provided more than enough nutrients for plant growth and fruit production.

Populations of specific chitinolytic microflora are stimulated by chitin 
amendment, and parasitize the nematode eggs and egg sacs (Spiegel et al. 1987). A relationship has been established between the chitinolytic ability of fungi and their capacity to destroy nematode eggs (Rodriguez-Kabana et al. 1984). A component of the middle layer of the egg shell of tylenchoid nematode is chitin, or a closely related material (Culbreath et al. 1985). There is also some evidence that chitin may be present in the gelatinous matrix of egg masses of Meloidogyne spp. (Spiegel and Cohn 1985). However, the unpasteurized organic soil used for this experiment may have not been colonized by this specific type of microflora, given that the chitin amendment was here ineffective.

Soil temperature affects ammonia release following chitin-urea mineralization (Spiegel et al. 1988). At $27^{\circ} \mathrm{C}$, ammonium concentration peaked after $15 \mathrm{~d}$ and almost vanished after $30 \mathrm{~d}$. Nitrate concentration steadily increased throughout the period. When efficient nitrification is established, ammonium is rapidly transformed into nitrate, provided soil temperatures remain warm (Tremblay and Perron 1991). Hence, ammonia in soil can be nematicidal at relatively high concentrations; such concentrations can only be found for a short period of time in warm soil conditions. Therefore, it is possible that, in our experiment, the nematodes were either not in a sensitive stage or not affected by this contact period when soil ammonia reached nematicidal concentrations.

Based on this experiment, it appears that chitin-urea amendments in organic soil do not have the same effect as in mineral soils and do not provide a reliable alternative for the control of $M$. hapla. The treatments used were within suggested rates, ranging 4.4-8.8 $\mathrm{t} \mathrm{ha}^{-1}$. At a cost of \$1.50-2.11 per kg, a grower would have payed out $\$ 6000-18568$ per ha. Even if the treatments had been effective, the costs were still 3-10 times higher than any other currently registered nematicide. The poor performance of the chitin-urea treatment in this experiment raises a concern about the cost and relevance of a widespread use of such non-chemical products for the control of plant-parasitic nematodes.
The $M$. hapla population from Quebec reduced top growth but did not affect yield of tomato $\mathrm{cv}$. Caruso. Based on its effect on N, P and Ca leaf composition, the nematode can be seen as a factor causing early senescence of the plant (Been and Schomaker 1986; Walworth and Sumner 1987). It has been suggested that the production of numerous secondary roots from $M$. hapla galled tomato roots and the absence of moisture or nutritional stresses contributed to the lack of effects on growth and yield of tomato under controlled conditions (Fawole and Mai 1979; Sayre and Toyama 1964). Our results support such hypothesis. Furthermore, Fawole and Mai (1979) have also shown that plant age at the time of transplanting and inoculum level of $M$. hapla are not important limiting factors for tomato growth under greenhouse conditions.

More investigations will be needed in the isolation of microorganisms such as bacteria or fungi, and the assessment of their potential as root pathogen of pesticide-free greenhouse tomatoes in Quebec.

\section{ACKNOWLEDGEMENTS}

We thank Y. Fournier and Y. Perron for their technical assistance.

\section{REFERENCES}

Barker, K.R., P.B. Shoemaker, and L.A. Nelson. 1976. Relationships of initial population densities of Meloidogyne incognita and M. hapla to yield of tomato. J. Nematol. $8:$ 232-239.

Been, T.H., and C.H. Schomaker. 1986. Quantitative analysis of growth, mineral composition and ion balance of the potato cultivar Irene infested with Globodera pallida (Stone). Nematologica 32 : 339335.

Carrier, A. 1992. Tomates de serre : une stratégie d'intervention contre les problèmes des racines. Pages 1-10 in Journées Horticoles Provinciales [Texte des conférences - Serriculture maraîchère, micro-informatique, culture maraîchère durable], ministère de l'Agriculture, des Pêcheries, et de I'Alimentation du Québec, Québec. 
Culbreath, A.K., R. Rodriguez-Kabana, and G. Morgan-Jones. 1985. The use of hemicellulosic waste matter for reduction of the phytotoxic effects of chitin and control of root-knot nematodes. Nematropica 15 : 49-75.

Fawole, B., and W.G. Mai. 1979. Influence of plant age, light, intensity, nematode inoculum level, and their interactions on tomato growth and reproduction of Meloidogyne hapla. J. Nematol. 11 : 199-201.

Isaac, R.A., and W.C. Johnson. 1976. Determination of total nitrogen in plant tissue using a block digestor. J. Assoc. Off. Anal. Chem. 59 : 98-100.

Mankau, R., and S. Das. 1969. The influence of chitin amendments on Meloidogyne incognita. J. Nematol. $1:$ 15-16 (Abstract).

Mian, I.H., G. Godoy, R.A. Shelby, R. RodriguezKabana, and G. Morgan-Jones. 1982. Chitin amendments for control of Meloidogyne arenaria in infested soil. Nematropica $12: 71-84$.

Olthof, Th.H.A., and J.W. Potter. 1977. Effects of population densities of Meloidogyne hapla on growth and yield of tomato. J. Nematol. $9: 296-300$.

Rodriguez-Kabana, R., G. Morgan-Jones, and B. Ownley-Gintis. 1984. Effects of chitin amendments to soil on Heterodera glycines, microbial populations, and colonization of cysts by fungi. Nematropica $14: 10-25$.

Rodriguez-Kabana, R., G. Morgan-Jones, and I. Chet. 1987. Biological control of nematodes : Soil amendments and microbial antagonists. Plant Soil $100: 237-247$.

SAS Institute Inc. 1988. SAS/STAT user's guide : release 6.03. SAS Institute Inc., Cary, North Carolina. 1028 pp.

Sayre, R.M., and T.K. Toyama. 1964. The effect of root-knot nematodes on the yield of processing tomatoes. Can. J. Plant Sci. $44: 265-267$.
Shelter, H., and B. Effmert. 1987. [Increase of Globodera rostochiensis (Wollw.,1923), pathotype 1, with organic matter content and organic or mineral fertilization of the soil] (in German). Arch. Acker-Pflanzenbau Bodenk-D. 31 : 487-493.

Spiegel, Y., and E. Cohn. 1985. Chitin is present in gelatinous matrix of Meloidogyne. Rev. Nématol. 8 : 184-185.

Spiegel, Y., E. Cohn, and I. Chet. 19816. Use of chitin for controlling plant-parasitic nematodes. I. Direct effects on nernatode reproduction and plant performance. Plant Soil $95:$ 87-95.

Spiegel, Y., I. Chet, and E. Cohn. 1987. Use of chitin for controlling plant-parasitic nematodes. II. Mode of action. Plant Soil 98 : 337-345.

Spiegel, Y., I. Chet, E. Cohn, S. Galper, and E. Sharon. 1988. Use of chitin for controlling plant-parasitic nematodes. III. Influence of temperature on nematicidal effect, mineralization and microbial population buildup. Plant Soil 109 : 251-256.

Stephan, Z.A. 1983. The effects of different densities of Meloidogyne ardenensis and of three populations of $M$. hapla on the growth of tomato at four soil temperatures. Nematol. medit. $11: 93-100$.

Townshend, J.L. 1963. A modification and evaluation of the apparatus for the Oostenbrink direct cotton-wool filter extraction method. Nematologica 9 : 106-110.

Tremblay, N., and Y. Perron. 1991. Transformation de l'urée dans un substrat tourbeux utilisé pour la production de transplants de céleri. Pages 38-43 in Actes Symposium 89 Tourbes et tourbières. Diversification et innovation. Volume II Nouveaux produits. Can. Soc. for Peat and Peatlands, Quebec, Canada.

Walworth, J.L., and M.E. Sumner. 1987. The diagnosis and recommendation integrated system (DRIS). Adv. Soil Sci. 6 : 149188. 